\title{
СУЧАСНІ ПІДХОДИ Й ІНСТРУМЕНТИ РЕАЛІЗАЦІЇ ВІДКРИТОЇ ОСВІТИ ТА ДИСТАНЦІЙНОГО НАВЧАННЯ
}

Ляхоцька Л. Л. Сучасні підходи й інструменти реалізації відкритої освіти та дистанційного навчання.

У статті показано роль відкритої освіти та дистанційного навчання в забезпеченні широкого доступу до якісної освіти та навчання протягом усього життя. Розкрито основні підходи щодо впровадження в освітній процес навчальних закладів України принципів та технологій відкритої освіти.

Ключові слова: відкрита освіта, дистанційне навчання, проектування технологій навчання, системи відкритої освіти, післядипломна педагогічна освіта.

Ляхоцкая Л. Л. Современные подходы и инструменты реализации открытого образования и дистанционного обучения.

В статье показана роль открытого образования и дистанционного обучения в обеспечении широкого доступа к качественному образованию и обучению в течение всей жизни. Раскрыты основные подходы к внедрению в образовательный процесс учебных заведений Украины принципов и технологий открытого образования.

Ключевые слова: открытое образование, дистанционное обучение, проектирование технологий обучения, системы открытого образования, последипломное педагогическое образование.

Lyahotska L. L. New approaches and tools of implementation of open education and distance learning.

The author reveals the role of open educational and distance learning in order to ensure greater access to quality education and lifelong learning. The paper deals with basic approaches to implementation of the principles and technologies of open education in the educational process in Ukraine.

Key words: open education, distance learning, design of learning technologies, systems of open education, postgraduate pedagogical education.

Низка чинників внутрішнього і зовнішнього характеру таких, як: невідповідність наявної якості освіти сучасним вимогам, недостатній ступінь упровадження в освітній процес IKT, недостатній доступ до якісної освіти, недостатня ефективність фінансування освіти, поглиблення диспропорції між підготовкою фахівців і попитом на них на ринку праці надає підстави говорити про необхідність реформування системи освіти і формування цілісної ефективної освітньо-наукової системи, що повною мірою відповідає вимогам часу. Негативний вплив на поточний стан системи освіти та її розвиток також зумовлює скорочення кількості учнів і студентів та недостатньо міцні позиції України на міжнародному освітньому ринку [2].

Стратегія розвитку освіти в Україні на період до 2021 року передбачає інтеграцію держави до світового освітнього простору, яка вимагає постійного вдосконалення національної системи освіти, пошуку ефективних шляхів підвищення якості освітніх послуг, апробації й упровадження інноваційних педагогічних систем, реального забезпечення рівного доступу всіх 
іï громадян до якісної освіти, можливостей і свободи вибору в освіті, модернізації змісту освіти й організації їі відповідно до світових тенденцій і вимог ринку праці, забезпечення безперервності освіти та навчання протягом усього життя, розвитку державно-громадської моделі управління [6].

Одним із перспективних шляхів подолання викликів інформаційного суспільства українською освітньою системою та забезпечення її поступального розвитку є впровадження відкритої освіти та дистанційного навчання. Саме застосування в освітньому процесі й освітньому менеджменті на всіх рівнях новітніх IKT та інноваційних методів роботи, що спираються на ці технології, може відіграти значну позитивну роль у реформуванні різних напрямів освітньої діяльності - від забезпечення ефективного моніторингу до створення цілісних систем забезпечення доступу до освітніх ресурсів та обміну передовим педагогічним досвідом і методичними матеріалами.

3-поміж останніх досліджень та публікацій, у яких започатковано розв’язання досліджуваної проблеми реалізації принципів відкритої освіти у відкритих педагогічних системах взагалі та в системі післядипломної педагогічної освіти зокрема, відзначимо роботи В. Бикова [1], С. Грема [9], Н. Клясен [3], В. Кухаренка [4], В. Олійника [7], Г. Чередніченко, Л. Шапран [8]. Водночас зауважимо, що означена проблема не повною мірою висвітлена в дослідженнях науковців.

Метою статті є розкрити роль відкритої освіти та дистанційного навчання в забезпеченні більш широкого доступу до якісної освіти та навчання протягом усього життя, а також розкрити основні підходи щодо впровадження в освітній процес закладів післядипломної педагогічної освіти принципів та технологій відкритої освіти.

Перехід до відкритих систем освіти у світовій практиці неперервної освіти характеризується суттєвими і глибокими змінами насамперед із таких питань освітньої діяльності, як:

- наближення змісту освіти до потреб, що формуються на ринку праці;

- формування й актуалізація нових педагогічних технологій, які базуються на якісних можливостях сучасних телекомунікацій та інформаційних систем;

- обгрунтування та практичне застосування принципово нових підходів до поєднання навчально-методичної та навчально-організаційної діяльності $\quad$ п процесі надання освітніх послуг;

- формування IT-підходів до організації навчально-методичної освітньої діяльності (створення електронних навчально-методичних комплексів, мережевих та мультимедійних підручників, систем електронного тестування, використання відеоконференцій та навчання через супутникові телекомунікації, навчання з використанням класів віддаленого доступу);

- відпрацювання нових організаційних механізмів регіонально розподільчих науковопедагогічних шкіл та розподіл кафедр;

- формування єдиних освітніх порталів та освітніх консорціумів.

Науковцями Інституту вищої освіти ЮНЕСКО [5] досліджено, що серед особливостей моделі відкритого навчання дорослих насамперед- відкритість і наявність прозорих кордонів між його навчальною та професійною діяльністю. Процес цілепокладання не обмежений рішенням суто навчальних завдань, а відбувається в широкому контексті цілей і проблем професійної діяльності дорослого учня, тобто в першу чергу передбачає розвиток у нього теоретичного мислення, формування комунікативних, креативних і рефлексивних здібностей. 
Навчання дорослих в Україні здійснюється через систему післядипломної освіти. Післядипломна освіта - новий вид освіти. Її виокремлення стало наслідком усвідомлення того, що за сучасних умов потреба суспільства в кваліфікованих кадрах з високим рівнем професіоналізму та культури може бути задоволена лише на основі нової філософії освіти «освіта через усе життя».

Слід зауважити, що існує сфера людської діяльності, яка не має відомчих меж і не може бути віднесеною до окремої галузі. До таких галузей належить насамперед діяльність із навчання людей - педагогічна діяльність. Законом України «Про загальну середню освіту» післядипломну педагогічну освіту виокремлено в самостійну структуру.

Інноваційний розвиток освіти України актуалізує проблему якісного оновлення післядипломної педагогічної освіти та ї̈ найважливішого складника - системи підвищення кваліфікації педагогічних працівників.

Однією $з$ ефективних форм неперервного підвищення кваліфікації педагогічних працівників $є$ змішане навчання. Упровадження такого навчання $є$ доволі кропітким $\mathrm{i}$ складним напрямом діяльності закладів післядипломної педагогічної освіти (ЗППО), оскільки його успішна реалізація залежить від наявності сучасних комп’ютерів, високошвидкісного Інтернету, відповідного ліцензійного програмного забезпечення для проведення занять в on-line та off-line режимах.

Комбіноване навчання означає використання різних методів подачі матеріалу для роботи у традиційному класі в поєднанні з дистанційним навчанням для досягнення цілей курсу [8]. Водночас К. Грем [9]. зазначає, що комбіноване навчання - це підхід, який інтегрує традиційне навчання та комп’ютерно опосередковане навчання в педагогічному середовищі. Зазначимо, навчання вважається комбінованим (змішаним), якщо дистанційне навчання становить від $20 \%$ до 80 \% [4].

Отже, можна виокремити три основні компоненти моделі комбінованого навчання, які використовуються в сучасному освітньому середовищі:

- очне навчання (face-to-face) - являє собою традиційний формат аудиторних занять викладач-слухач;

- самостійне навчання (self-study learning) - передбачає самостійну роботу слухачів: пошук матеріалів за допомогою ресурсної карти, пошук в мережі тощо;

- онлайн-навчання (online collaborative learning) - робота слухачів і викладачів у режимі онлайн, наприклад, за допомогою інтернет-конференцій, скайпу або вікі тощо.

За проведеним нами дослідженням щодо модернізації освітньої діяльності закладів ППО упродовж останніх років активно впроваджується дистанційна форма навчання та ії технології в освітній процес ЗППО [8]. У регіонах триває процес створення єдиного соціального інформаційно-освітнього середовища, яке забезпечуватиме можливість професійного зростання кожного педагога, відпрацьовуються й запроваджуються інноваційні моделі.

Вагомим напрямом інформаційного та науково-методичного забезпечення педагогічних працівників $\epsilon$ створення сайтів, електронних бібліотек, очного та дистанційного консультування на базі інтернет-ресурсів тощо. Нині в усіх закладах післядипломної освіти використовуються можливості інформаційно-освітнього середовища, що створює умови вільного доступу до інформаційних та освітніх ресурсів на основі використання сучасних інформаційних технологій, телекомунікаційних мереж, навчання в режимі on-line тощо. 
На веб-сайтах закладів ППО та методичних служб педагогічні працівники мають змогу ознайомитися 3 нормативно-правовими документами, навчальними планами та програмами; методичною та науково-методичною літературою, інформаційними ресурсами 3 певних дисциплін; новими технологіями і методиками навчання і виховання; науковими розробками з інноваційних напрямів освіти; новими моніторинговими дослідженнями; науковими та методичними доробками колег, інтерактивного спілкування тощо.

Значна увага надається створенню єдиної інформаційної мережі установ та закладів освіти, упровадженню інноваційних освітніх проектів в управлінську діяльність та навчально-виховний процес («Intel@Навчання для майбутнього», «Microsoft@ «Партнерство у навчанні», «1 учень - 1 комп’ютер», «Темпус», «Освіта в Україні. Нормативно-правове регулювання», «Інформаційне забезпечення загальноосвітнього навчального закладу»). У планах третій проект - «Єдиний реєстр навчально-методичних розробок» [4].

Водночас систему післядипломної педагогічної освіти (підвищення кваліфікації) ми ще не можемо назвати відкритою. У табл. 1 наведено основні показники чинної системи підвищення кваліфікації та їх узагальнена характеристика відповідно до показників відкритої освіти.

Таблиця 1

\section{Показники відкритої освіти та характеристики чинної системи післядипломної} педагогічної освіти (підвищення кваліфікації)

\begin{tabular}{|c|c|c|}
\hline № & $\begin{array}{c}\text { Показники } \\
\text { відкритої освіти }\end{array}$ & Характеристики \\
\hline 1 & 2 & 3 \\
\hline 1 & Доступність & $\begin{array}{l}\text { Регламентована: набір слухачів планується } \quad \text { та } \quad \text { здійснюєтьс } \\
\text { органами державного управління освітою }\end{array}$ \\
\hline 2 & Неперервність & $\begin{array}{l}\text { Практично відсутня: курсова підготовка, як правило, один раз на } 5 \\
\text { років; система міжкурсової підготовки - малоефективна. }\end{array}$ \\
\hline 3 & Відкри & $\begin{array}{l}\text { Система залишається закритою: функціонує в межах галузі, відсутні } \\
\text { повномасштабне міжнародне співробітництво та досвід співпраці з } \\
\text { аналогічними системами інших галузей, обмін інформацією - на } \\
\text { регіональному рівні. }\end{array}$ \\
\hline 4 & Сучасң & $\begin{array}{l}\text { Не в повному обсязі: у навчальному процесі недостатньо } \\
\text { застосовуються сучасні iнформаційні технології, персональні } \\
\text { комп’ютери, оргтехніка, телекомунікаційні технології та мережі. }\end{array}$ \\
\hline 5 & $\begin{array}{l}\text { Особистісна } \\
\text { орієнтованість }\end{array}$ & $\begin{array}{l}\text { Недостатня: зміст і умови навчання задані та розраховані на } \\
\text { «середнього» слухача, варіативність практично забезпечується } \\
\text { недостатньо. }\end{array}$ \\
\hline 6 & Економічність & $\begin{array}{l}\text { Низька: на період курсової підготовки слухачам (у кращому } \\
\text { випадку) сплачуються середня заробітна плата, проїзд, відрядження } \\
\text { тощо. }\end{array}$ \\
\hline 7 & $\begin{array}{l}\text { Інерційність змісту } \\
\text { навчання }\end{array}$ & $\begin{array}{l}\text { Менша ніж у ВНЗ, але також має місце. Періодична корекція } \\
\text { навчальних планів і програм повністю проблему не розв’язує. }\end{array}$ \\
\hline 8 & $\begin{array}{l}\text { Дидактичне } \\
\text { методичне } \\
\text { забезпечення } \\
\text { освітнього процесу } \\
\end{array}$ & $\begin{array}{l}\text { i Недостатнє: мало спеціалізованої літератури, методик тощо; } \\
\text { бібліотечні фонди частково застаріли; сучасна видавнича база } \\
\text { відсутня. Сучасні носії інформації застосовуються не повною } \\
\text { мірою. }\end{array}$ \\
\hline 9 & Упровадження & використовуються \\
\hline
\end{tabular}




\begin{tabular}{|c|c|c|}
\hline № & $\begin{array}{c}\text { Показники } \\
\text { відкритої освіти }\end{array}$ & Характеристики \\
\hline & $\begin{array}{l}\text { дистанційної форми } \\
\text { навчання }\end{array}$ & 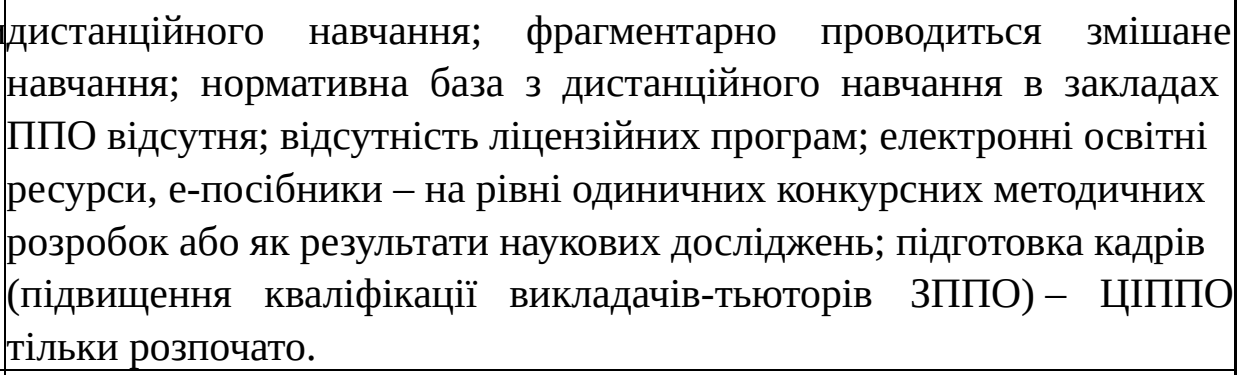 \\
\hline 10 & \begin{tabular}{|l} 
Інформаційне \\
освітнє середовище
\end{tabular} & Відкрите на регіональному рівні. \\
\hline
\end{tabular}

Із даних таблиці 1 видно, що вітчизняна система підвищення кваліфікації за основними показниками не задовольняє вимог, які ставляться до відкритих систем освіти.

Необхідність реформування системи післядипломної педагогічної освіти назріла досить давно. У реформуванні системи підвищення кваліфікації, насамперед зацікавлені ії користувачі: керівники і спеціалісти органів управління освітою, методисти всіх рівнів, керівний та викладацький склад навчальних закладів тощо.

Як свідчать проведені нами дослідження, абсолютна більшість педагогічних працівників є прихильниками змін у системі підвищення кваліфікації (змісту - 83,3 \%, організації - 76,0 \%, форм і методів навчання - 75,0 \%).

Аналіз загальносвітових тенденцій реформування національних систем освіти задля надання їм характеристик відкритої показує, що одним 3 найефективніших способів вирішення цього завдання є проектування технологій навчання в освітній процес ЗППО.

Нами визначено, що під час проектування технології навчання як педагогічний об’єкт постає педагогічна технологія навчання - послідовна взаємопов’язана система дій педагога, спрямована на процес передачі знань, умінь і навичок.

Із зазначеного вище педагогічне проектування технологій навчання нами розглядається як процес створення педагогічних технологій навчання. Визначимо етапи цього процесу:

1. Здійснення теоретичної моделі технологій навчання, виявлення їх істотних властивостей; аналіз принципів та умов функціонування.

2. Розроблення проектної моделі технологій навчання:

1) визначення бази знань - інформаційної моделі досліджуваного матеріалу;

2) розроблення педагогічної моделі знань: структурування матеріалу, вибір і «обмірковування» його подання (тем, питань);

3) розроблення моделі педагогічного спілкування: ланцюжок педагогічних дій, операцій, комунікацій, взаємопов’язана діяльність викладача і слухачів тощо.

3. Практична реалізація та апробація моделі технологій навчання: проведення педагогічного експерименту на невеликій групі слухачів.

4. Аналіз результатів експерименту і коректування моделі технологій навчання.

Ми пропонуємо проектну модель технології навчання в системі відкритої післядипломної педагогічної освіти, яка має технологічний складник з компонентами:

- інформаційний (персональний веб-ресурс, електронний навчально-методичний комплекс, масовий відкритий онлайн-курс);

- технологічний (сервіси та інструменти Google, системи управління навчальними 
ресурсами - платформа eFront).

- педагогічний (технології проектного та змішаного навчання).

На основі проектування інформаційно-педагогічних технологій навчання відбувається інтеграційний процес освітньої діяльності ЗППО до відкритої системи, головна перевага якої полягає в тому, що вона одночасно сприяє як підвищенню дієвості освітніх систем, так i зниженню витрат на їх утримання. Відкрите і дистанційне навчання робить освіту максимально мобільною, динамічною і керованою. До основних сучасних проблем, які залишаються перспективою подальших досліджень, віднесемо недостатню розробленість теорії навчання у відкритих педагогічних системах, несформованість іiї поняттєвотермінологічного апарату, готовність науково-педагогічних і педагогічних працівників до роботи у відкритих педагогічних системах.

\section{Література}

1. Биков В. Ю. Моделі організаційних систем відкритої освіти: [монографія] / В. Ю. Биков. - Київ : Атіка. 2009. - 684 с. 2. Здіорук С. І. Формування єдиного відкритого освітньо-наукового простору України: оптимальне використання засобів забезпечення випереджального розвитку: аналітична доповідь / С. І. Здіорук, А. Ю. Іщенко, M. М. Карпенко. - $\quad$ Режим доступу : Science_educationl-e2f67.pdf11. $\quad$ 3. Клясен Н. Л. Діяльність закладів післядипломної педагогічної освіти в умовах модернізації освітньої галузі в Україні / Н. Л. Клясен // Післядипломна освіта в Україні. - 2014. - Вип. 2. - С. 10-13.

4. Кухаренко В. Н. Комбинированное (смешанное) обучение [Электронный ресурс] / В. Н. Кухаренко. - Режим доступа : http://kvn-e-learning. blogspot.com/2012/08/blogpost_22.html. 5. Мур Майкл Г. Открытое и дистанционное обучение: тенеденции, политика и стартегии / Майкл Г. Мур, А. Тэйт, П. Реста [и др.]. - Москва : Мзд.ИНТ, 2004. - 139 с. 6. Національна стратегія розвитку освіти в Україні на період до 2021 року [Електронний ресурс]. - Режим доступу : http://www.president.gov.ua/ru/documents/15828.html. 7. Олійник В. В. Освітня діяльність вищих навчальних закладів післядипломної педагогічної освіти: [довідник] / В. В. Олійник, В. О. Гравіт, Л. Л. Ляхоцька [за заг. ред. В. В. Олійника]. НАПН України, Ун-т менедж. освіти. - Донецьк : Донбас, 2012.- 151 с. 8. Чередніченко Г. А. Модель змішаного навчання і її використання у викладанні іноземних мов / Г. А. Чередніченко, Л. Ю. Шапран. - Режим доступу : http://2015. Moodlemoot.in.ua/ course/view.php?id=83\&lang=en. 9. Graham C. R. (2005). Blended learning systems: Definition, current trends, and future directions. In C. J. Bonk \& C. R. Graham (Eds.). Handbook of blended learning: Global perspectives, local designs (pp. 3 - 21). San Francisco, CA : Pfeiffer Publishing.

УДК 621.38

Володимир Макаренко, Віктор Співак

\section{СХЕМОТЕХНІЧНЕ МОДЕЛЮВАННЯ ЯК ЗАСІБ ДЛЯ ПОЯСНЕННЯ ПРОЦЕСІВ, ЩО ВІДБУВАЮТЬСЯ В ЕЛЕКТРИЧНИХ КОЛАХ}

Макаренко В. В., Співак В. М. Схемотехнічне моделювання як засіб для пояснення процесів, що відбуваються в електричних колах.

У статті розглянуто на конкретному прикладі можливість використання програми імітаційного моделювання NI Multisim для пояснення й ілюстрації складних процесів, що відбуваються у радіоелектронних пристроях. Обгрунтовано вибір програми моделювання для аналізу схемотехнічних рішень з точки зору функціональності і вартості їі придбання. 